\title{
OCTOMERIA CANDIDAE (ORCHIDACEAE: PLEUROTHALLIDINAE), A NEW SPECIES FROM THE CORDILLERA DEL CÓNDOR, ECUADOR
}

\author{
Leisberth Vélez-Abarca ${ }^{1,4-5}$, Marco M. JiméNeZ ${ }^{2,4} \&$ Luis E. Baquero ${ }^{3,4}$ \\ ${ }^{1}$ Carrera de Biología, Universidad Estatal Amazónica (Sede El Pangui), Luis Imaicela \\ entre Azuay y Mayor Rene Ulloa, El Pangui, Zamora Chinchipe, Ecuador \\ ${ }^{2}$ Orquideario La Paphinia, Zamora, Ecuador \\ ${ }^{3}$ Grupo de Investigación en Biodiversidad, Medio Ambiente y Salud BIOMAS. \\ Carrera de Ingeniería Agroindustrial y Alimentos, Facultad de Ingeniería y Ciencias Agropecuarias, \\ Universidad de Las Américas, Quito, Ecuador \\ ${ }^{4}$ Grupo Científico Calaway Dodson: Investigación y Conservación de Orquídeas del Ecuador, \\ Quito, Ecuador \\ ${ }^{5}$ Author for correspondence: leis.alexis92@gmail.com
}

\begin{abstract}
A new species of Octomeria from southern Ecuador was found during an investigation on the orchids of the Cordillera del Cóndor. Octomeria candidae is described and illustrated; likewise, information on its distribution, habitat and conservation status is provided. The new proposed taxon is morphologically similar to $O$. estrellensis, from which it differs by its creeping habit, the narrowly ovate, long-acuminate sepals and petals, and the yellow lip with an acute apex.

Resumen. Una nueva especie de Octomeria del sur de Ecuador fue encontrada durante una investigación sobre las orquídeas de la Cordillera del Cóndor. Se describe e ilustra a Octomeria candidae; así mismo, información sobre su distribución, hábitat y estado de conservación es brindada. El nuevo taxón propuesto es morfológicamente similar a $O$. estrellensis, del cual se diferencia por su hábito rastrero, los sépalos y pétalos estrechamente ovados, largamente acuminados y el labelo amarillo con el ápice agudo.
\end{abstract}

Key Words / Palabras clave: Actividad minera, Conservación de orquídeas, Mining activities, New orchid species, nueva especie, Octomeria estrellensis, Orchid conservation, Zamora Chinchipe

Introduction. Octomeria R.Br. is a neotropical genus of Pleurothallidinae proposed by Robert Brown in 1813 when he described Octomeria graminifolia (L.) R.Br. (Pridgeon 2006, Luer 2010). According to previous molecular studies (Pridgeon et al. 2001, Pridgeon 2006), Octomeria is a monophyletic taxon. Plants of this genus are epiphytic, repent to caespitose. Leaves are conduplicate, flat to terete or semiterete; nevertheless, in some species the morphological boundaries are not clear. The flowers are fasciculate to solitary, emerging from the apex of the ramicaul. The sepals and petals are very similar, but unequal in size and the lateral sepals can be free or occasionally connate. The column is semiterete, usually with a subapical anther and stigma, the pollinarium is generally comprised of eight pollinia, except for one species $(O$. splendida Garay \& Dunst.) which has only 6 pollinia (Cogniaux 1896, Luer 2010).
With approximately 160 species, Octomeria is distributed from Belize to northern Argentina, the center of diversity being from the Guianas to South Brazil (Forster 2007, Forster et al. 2012, Karremans et al. 2019). In Ecuador, 26 species of the genus are currently reported, of which, $O$. doucetteana L.E.Matthews, is the most recently described species for this country (Matthews 2018). In the Zamora Chinchipe province, there are eleven species registered (Luer 2010, 2011, Forster et al. 2012), which is the area with the highest diversity of the genus in the country. A recently discovered species from southeast Ecuador is described here.

Materials and methods. Plants of the new species were collected during a research on orchids of the Cordillera del Cóndor, under permits granted by the Ministerio del Ambiente de Ecuador. Some specimens 

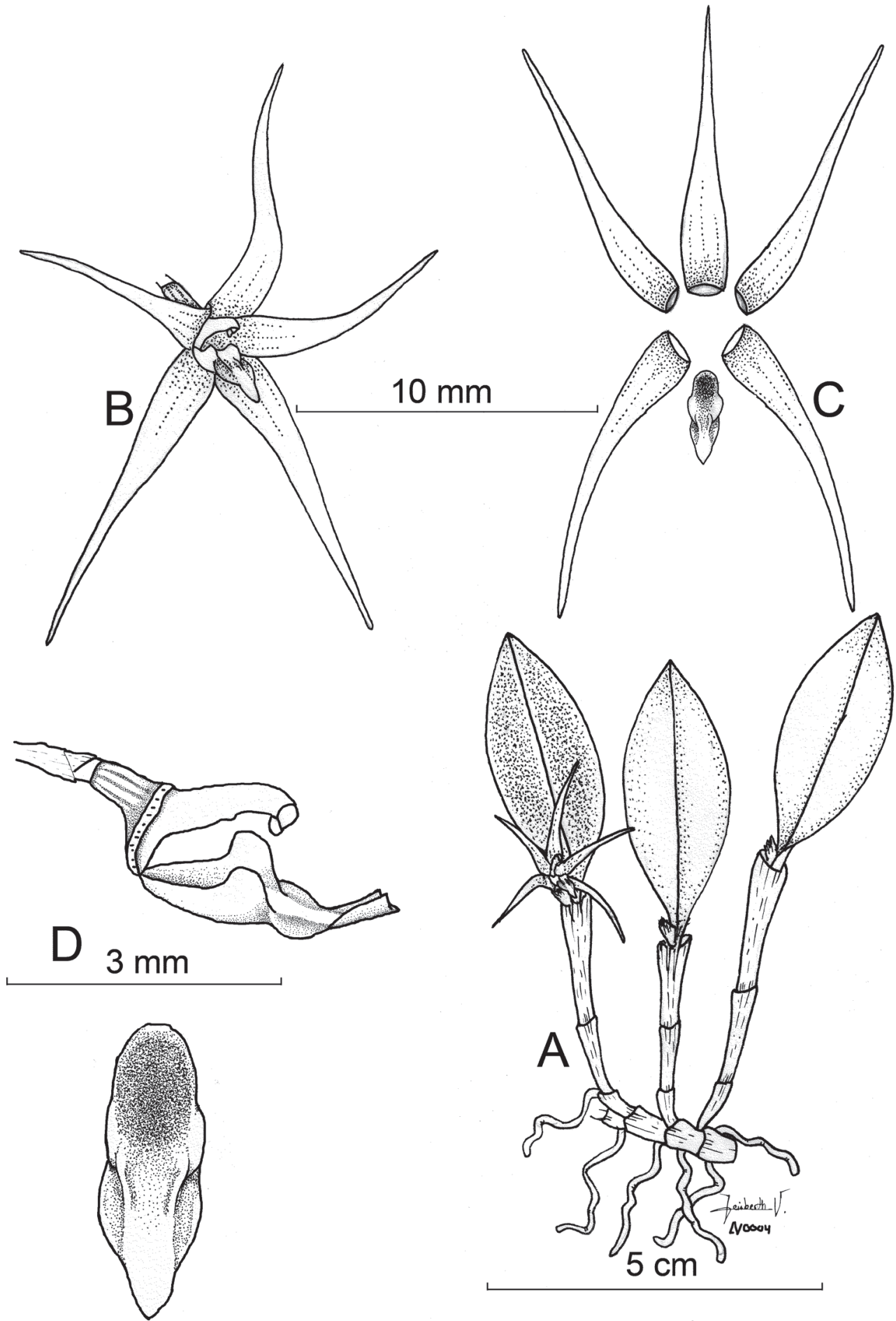

Figure 1. Octomeria candidae Vélez-Abarca, M.M.Jiménez \& Baquero. A. Habit. B. Flower in 3/4 view. C. Dissected perianth. D. Part of the pedicel, ovary, column and lip in lateral view and lip dorsal view. Illustration by Leisberth Vélez-Abarca, based on the holotype, Vélez-Abarca LV-0004 (ECUAMZ). 
were cultivated and photographed at the Orquideario La Paphinia in Zamora, Ecuador. Fresh flowers and inflorescences of live plants were stored in $70 \%$ ethanol and glycerol. Measurements of the vegetative and floral parts were made from living and alcohol stored material.

Digital images were taken with a Panasonic ${ }^{\circledR}$ FZ300 camera with a Raynox DCR-150 50 mm lens; also, with a Canon ${ }^{\circledR}$ EOS 1100 D camera with an EFS $18-58 \mathrm{~mm}$ lens and approximation lenses +10 Kernel Pro Optics $58 \mathrm{~mm}$.

The taxonomic revision of Octomeria by Luer (2010) and other original descriptions from holotypes of related species (Hoehne 1950, Santos et al. 2020) were consulted and compared.

\section{TAXONOMIC TREATMENT}

Octomeria candidae Vélez-Abarca, M.M.Jiménez \& Baquero sp. nov. (Fig. 1-4).

TYPE: Ecuador. Zamora Chinchipe: Cordillera del Cóndor flank, 890 m, 18 February 2020, L. Vélez LV0004 (holotype: ECUAMZ!)

Diagnosis: Similar to Octomeria estrellensis Hoehne, from which it differs by the short, repent rhizome, the longer ramicauls, the narrowly ovate, long-acuminate dorsal sepal; and the yellow lip concave below the middle.

Plant small up to $8 \mathrm{~cm}$ tall, epiphytic, shortly repent. Rhizome stout, $5 \mathrm{~mm}$ thick, $0.5-1.0 \mathrm{~cm}$ long between ramicauls. Roots ca. $0.5 \mathrm{~mm}$ in diameter, flexuous, white. Ramicauls slender, erect, $0.5-5.0 \mathrm{~cm}$ long, cylindrical, with 1-3 internodes enclosed by loose, tubular, sheaths, which are torn with age. Leafs sometimes suffused with purple abaxially and at the edges of the adaxial part, erect, coriaceous, fleshy, elliptical to narrowly ovate, $1.5-4.0 \times 0.8-1.2 \mathrm{~cm}$, the midvein sulcate adaxially and carinate abaxially, margin entire, cuneate at the base into a petiole, 3 $\mathrm{mm}$ long. Inflorescence of a single flower, rarely 2 simultaneous, produced successively from the apex of the ramicaul; peduncle terete, $2.5-3.0 \mathrm{~mm}$ long; floral bract 1 infundibuliform, membranaceous, 2.5-3.0 mm long; pedicels cylindrical, $3 \mathrm{~mm}$ long; ovary $2 \mathrm{~mm}$ long, somewhat obconical, sulcate and slightly curved. Sepals and petals translucent pink to orange, free, glabrous. Dorsal sepal lanceolate, long-acuminate, $1.0-1.2 \times 0.2-0.3 \mathrm{~cm}, 3$-veined. Lateral sepals lanceolate, falcate, long-acuminate, $1.0-1.2 \times 0.1-0.2 \mathrm{~cm}, 3$-veined. Petals narrowly ovate, long-acuminate, $1.0-1.2 \times 0.2-0.3 \mathrm{~cm}$, 3 -veined. Lip yellow, oblong, panduriform, trilobed, glabrous, $3.0 \times 1.5 \mathrm{~mm}$, with lateral lobes erect, rounded, the apical lobe ovate, slightly thickened above the middle, concave below the middle; base truncate, not articulated to the column foot. Column semiterete, $2 \mathrm{~mm}$ long, foot $1.5 \mathrm{~mm}$ long, stigma ventral, clinandrium entire, margin slightly dentate. Anther cap subapical. Pollinia 8, in 2 sets of 4, yellow, clavate.

Eponymy: Named after Candida Mashendo, wife of the main author, who first spotted this species.

Distribution AND Habitat: The holotype of this species was found in a flank of the Cordillera del Cóndor, located in the Zamora Chinchipe Province, Ecuador. The species is found between $890-980 \mathrm{~m}$ in low premontane forests on sandstone plateaus. The species grows as an epiphyte on branches of trees and shrubs of Dacryodes peruviana (Loes.) H.J.Lam, (Burseraceae) and Schefflera sp. (Araliaceae).

Octomeria candidae is morphologically similar and presumably related to species in sect. Octomeria subsect. Octomeria (sensu Luer 1986): O. cochlearis Rchb.f. (Reichenbach 1881), O. montana Barb. Rodr. (Barbosa Rodrigues 1882) O. ochroleuca Barb.Rodr (Barbosa Rodrigues 1877), O. lilliputana W.Forst., F.Barros \& V.C.Souza (Foster et al. 2013) and O. estrellensis Hoehne (Hoehne 1950), the latter being the most similar species, which is characterized by being the only small species known to have fleshy, obovate to elliptical leaves and an elongated peduncle. However, $O$. candidae is the second known species in the genus to share these characteristics. Despite the fact that both species are similar, $O$. candidae is distributed in southern Ecuador, and $O$. estrellensis is distributed further south in Brazil. Octomeria candidae is distinguished from $O$. estrellensis by the short repent habit, thicker rhizome ( $v s$. caespitose habit, inconspicuous rhizome), the longer ramicauls, 5-50 mm long (vs. 5-10 mm long), the shorter 

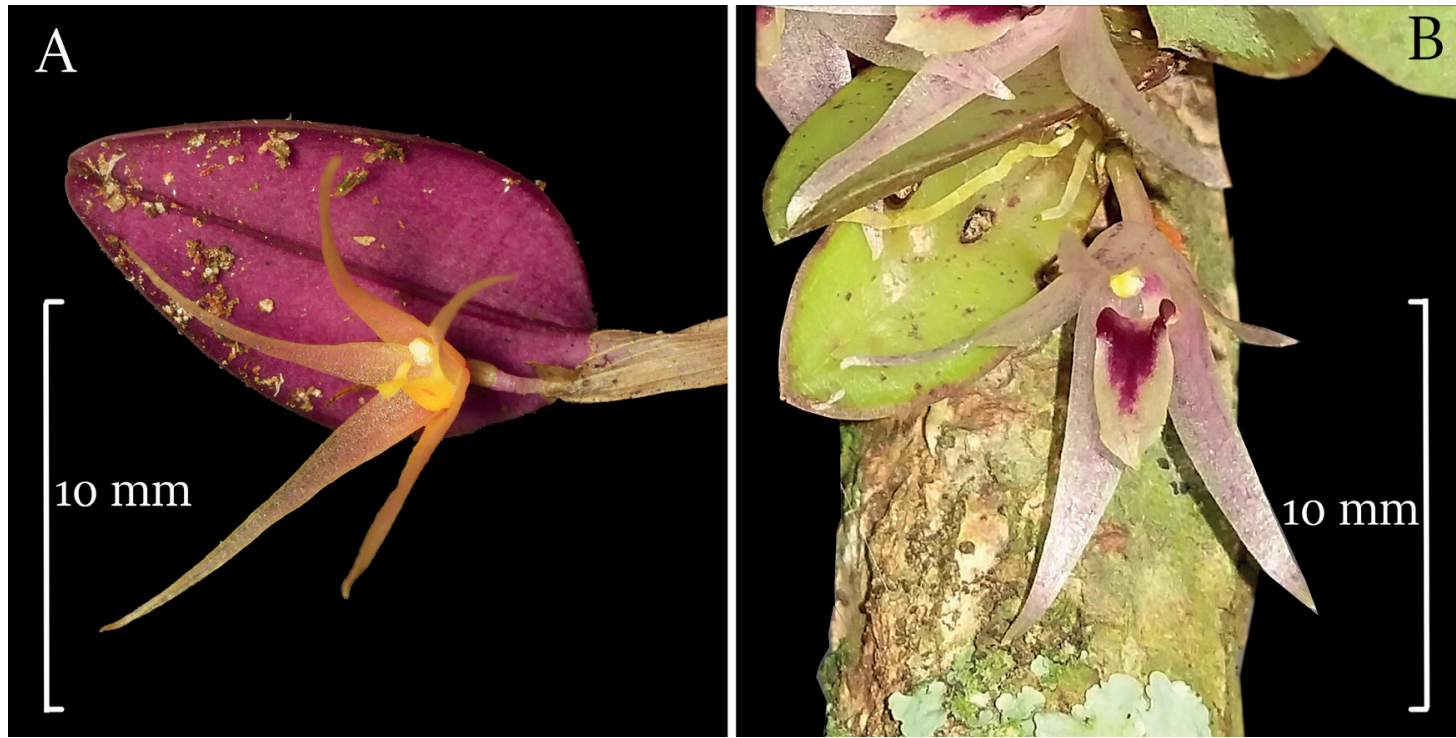

Figure 2. Comparison of flowers of Octomeria candidae Vélez-Abarca, M.M.Jiménez \& Baquero and O. estrellensis Hoehne. A. Flower of $O$. candidae in situ. B. Flower of $O$. estrellensis in cultivation. Photos by Marco M. Jiménez (A) and Marcos Da Silva (B).

pedicels, $3 \mathrm{~mm}$ long (vs. $5 \mathrm{~mm}$ long), the dorsal sepal narrowly ovate, long-acuminate (vs. oblonglanceolate, acute to acuminate), the petals narrowly ovate, long-acuminate (vs. oblong-lanceolate, acute to acuminate), and the yellow lip, concave below the middle, acute at the apex (vs. the red-purple at the base and center, and greenish yellow at the apical third, acute to rounded at the apex) (Fig. 2).

In the study area, a considerable population of Octomeria candidae was found, which expresses high vegetative variability. The individuals that were found under shade showed greater vegetative development, since they have more elongated ramicauls, larger and wider leaves, and green on the adaxial and abaxial surfaces (Fig. 3B). While those that receive direct sunlight in more degraded areas are smaller, they present a purplish-red pigmentation in the abaxial and adaxial side of the leaves, in some cases only abaxially (Fig. 3C). The flowers of individuals exposed to greater solar radiation have a larger size compared to the flowers of those that are under shade (Fig. 4).
Conservation status: This species has not been found yet in other localities of Ecuador, currently reported only in the province of Zamora Chinchipe (Fig. 5). The known populations of this species grow in disturbed forests where mining activity is practiced. Because of the considerable presence (1-10) of individuals per phorophyte observed, future problems due to destruction of the habitat are expected for this species since it has only been found outside of protected areas.

AcKnOwLedGMents. We acknowledge Mark Wilson for helping with language corrections and other observations in this manuscript. To the Ministerio del Ambiente (MAE) for granting the Research Permits No. 037-2019-IC-FLOFAU-DPAZCH-UPN-VS/MA and 021-2019-IC-FLOFAU-DPAZCH-UPN-VS/MA. We thank Universidad Estatal Amazónica (UEA) and Universidad de las Américas (UDLA) for funding orchid research in Ecuador. We also want to thank Marcos Da Silva for giving us permission to use his photos. We thank Marco Monteros for his help in elaboration the distribution map. The authors also acknowledge the reviewers of this manuscript for helping with comments and corrections to this work.

Right, Figure 3. Morphological and color variation in leaves of Octomeria candidae. A. Variation in length, width and shape of the leaf blade, adaxial side. B. Adaxial and abaxial side of leaves with light coloration. C. Adaxial and abaxial side with green and light purple red, respectively and dark edges. D. Adaxial and abaxial side with intense green and purple red, respectively, in addition to having a completely obtuse apex. E. Blade adaxially green with dark edges and abaxially partially dark. Photos by Marco M. Jiménez and Leisberth Vélez-Abarca. 

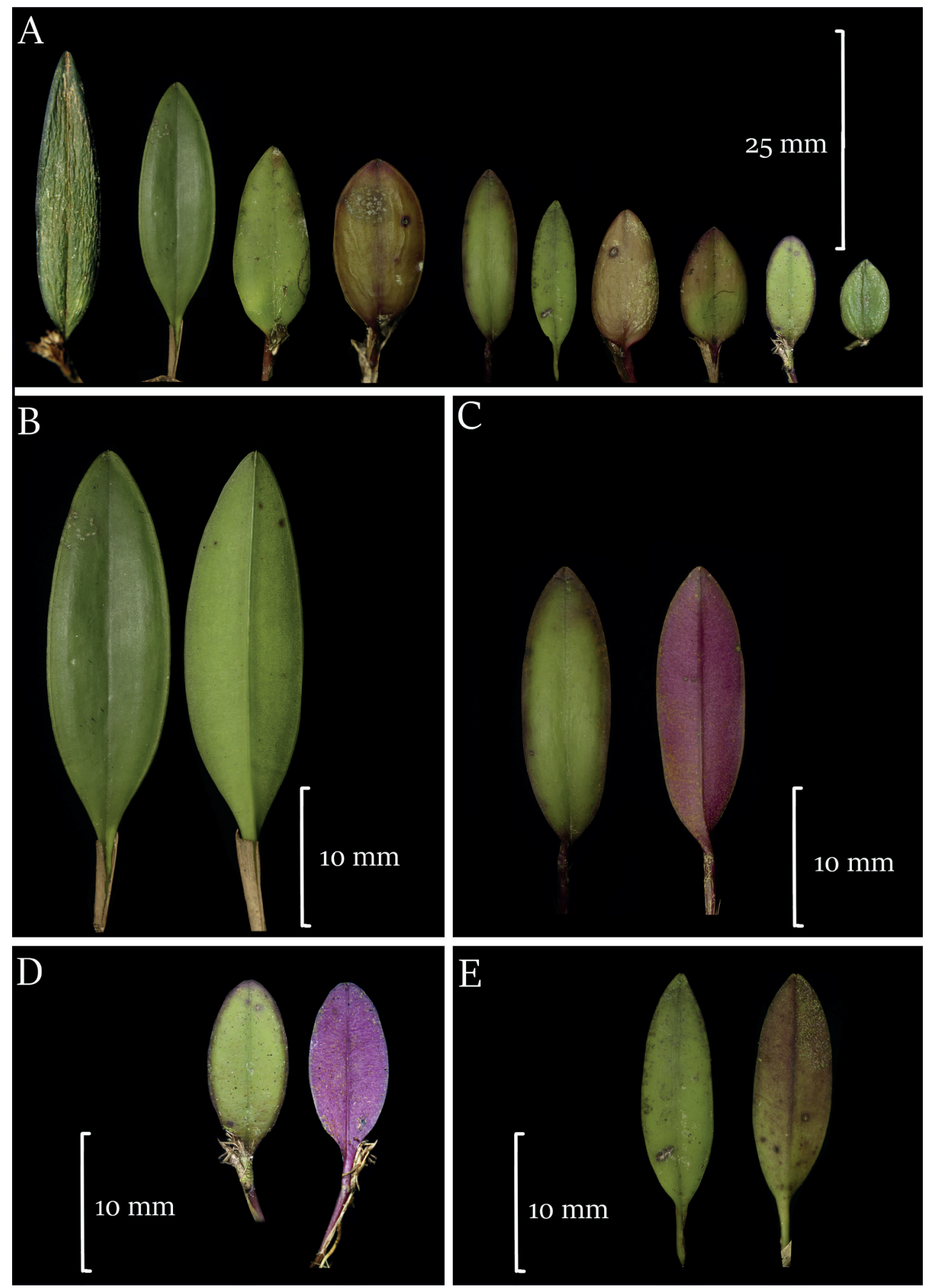

LANKESTERIANA 20(3). 2020. (C) Universidad de Costa Rica, 2020. 

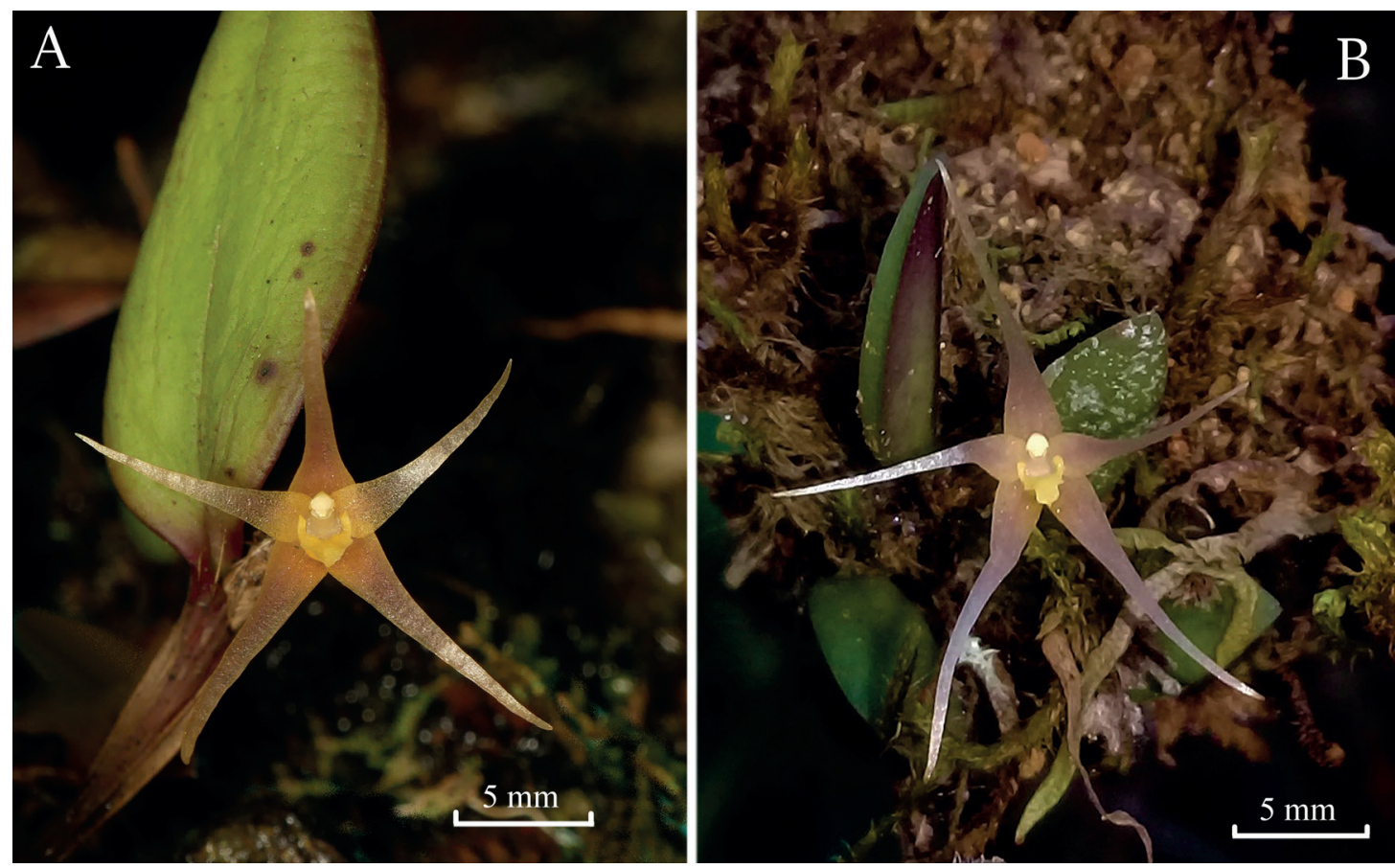

Figure 4. Comparison of two Octomeria candidae plants in situ. A. Large plant with slightly smaller flower. B. Smaller plant with slightly larger flowers. Photograph by Marco M. Jiménez (A), Leisberth Véle-Abarca.

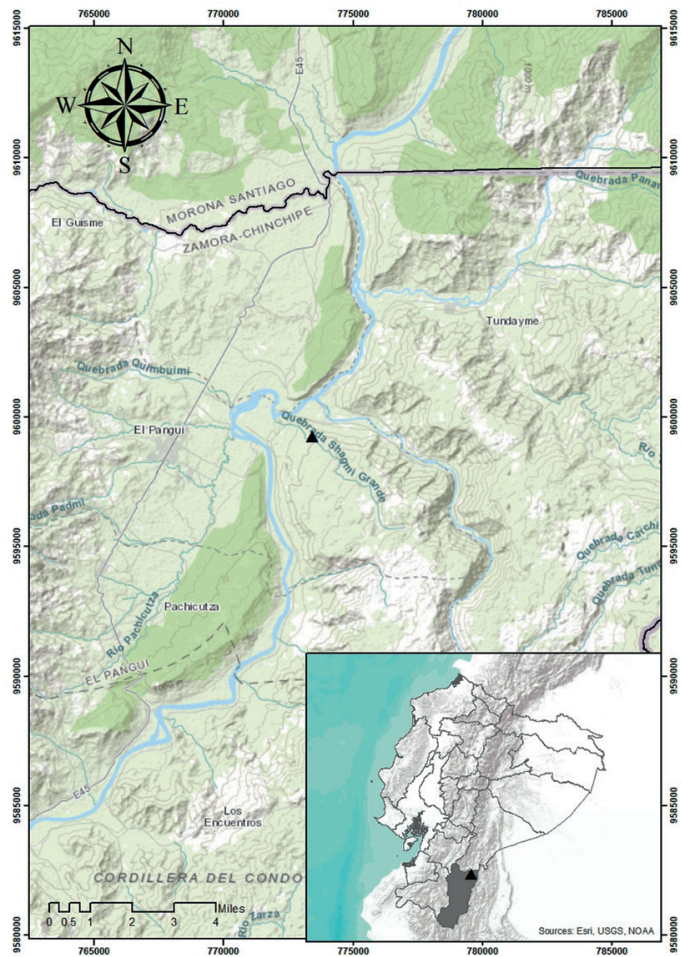

FIGURE 5. Distribution map of Octomeria candidae in Ecuador. Created by Marco F. Monteros.
LiTERATURE CITED

Barbosa Rodrigues, J. (1877). Genera et Species Orchidearum novarum, 1. Sebastianópolis: C. \& H. Fleiuss. 209 pp.

Barbosa Rodrigues, J. (1882). Genera et Species Orchidearum novarum, 2. Rio de Janeiro: Typographia Nacional. 295 pp.

Brown, R. (1813). Octomeria graminifolia R.Br. In: W. Aiton (Ed.), Hortus Kewensis, 2nd edition, volume 5 (p. 211). London: Richard Taylor and Co.

Cogniaux, A. C. (1896). Orchidaceae, Tribus VI: Pleurothallidinae. In: C. F. P. Martius, A. G. Eichler \& I. Urban (Eds.), Flora Brasiliensis, volume 3, part 4, 320-646. Monachii et Lipsiae [Munich \& Leipzig]: R. Oldenbourg.

Forster, W. (2007). Estudo taxonômico das espécies com folhas planas a conduplicadas do gênero Octomeria R.Br. (Orchidaceae). Ph.D. Thesis, Universidade de São Paulo, São Paulo, 270 pp.

Forster, W., Castro, V. \& De Barros, F. (2012). Three new species of Octomeria (Orchidaceae: Pleurothallidinae) from northern South America. Kew Bulletin, 67, 487493.

Forster, W., Souza, V. C., \& De Barros, F. (2013). Octomeria lilliputana (Orchidaceae), a new species from Brazilian Atlantic Forest, State of Paraná, Brazil. Phytotaxa, 105(2), 39. 
Hoehne, F. C. (1950). Octomeria da afinidade de $O$. chamaeleptotes Rchb.f. do Brasil Austral. Arquivos de Botânica do estado de São Paulo, 2, 111-115.

Karremans, A. P., Aguilar-Sandí, D., Artavia-Solís, M., Cedeño-Fonseca, M., Chinchilla, I. F., Gil-Amaya, K., Rojas-Alvarado, G., Solano-Guindon, N. \& Villegas-Murillo, J. (2019). Nomenclatural notes in the Pleurothallidinae (Orchidaceae): miscellaneous. Phytotaxa, 406(5), 259-270.

Luer, C. A. (1986). Icones Pleurothallidinarum I. Systematics of the Pleurothallidinae (Orchidaceae). Monographs in Systematic Botany from Missouri Botanical Garden, 15, 1-81.

Luer, C. A. (2010). Icones Pleurothallidinarum XXXI. Lepanthes of Bolivia, Systematics of Octomeria Species North and West of Brazil, Addenda: New Species of Brachionidium, Lepanthes, Masdevallia, Octomeria, Platystele, Pleurothallopsis, and Porroglossum. Corrigenda. Monographs in Systematic Botany from Missouri Botanical Garden, 120, 1-154.

Luer, C. A. (2011). Miscellaneous new species in the
Pleurothallidinae (Orchidaceae) excluding species from Brazil. Harvard Papers in Botany, 16(2), 311360 .

Matthews, E. (2018). Eight new species of Pleurothallidinae (Orchidaceae). Described from the collection of Alfonso Doucette. Orchideen Journal, 6(3), 1-14.

Pridgeon, A. M., Solano R. \& Chase M. W. (2001). Phylogenetic relationships in subtribe Pleurothallidinae (Orchidaceae): combined evidence from nuclear and plastid DNA sequences. American Journal of Botany 88(12),2286-2308. Doi: http://dx.doi. org/10.2307/3558390

Pridgeon, A. M. (2006). Octomeria. In: A. M. Pridgeon, P. J. Cribb, M. W. Chase, \& F. N. Rasmussen (eds), Genera Orchidacearum, 4, Epidendroideae (part 1) (pp. 375378). Oxford: Oxford University Press.

Reichenbach, H. G. (1881). New Garden Plants. The Gardeners' Chronicle, 15, 266.

Santos, T., Toscano de Brito, A. \& Smidt, E. C. (2020). Octomeria (Orchidaceae: Pleurothallidinae) no estado do Paraná, Brasil. Rodriguésia, 71, 1-37. 
LANKESTERIANA 